\title{
ANALISIS PEMBENTUKAN EKUITAS MEREK BERDASARKAN CITRA MEREK, WORD OF MOUTH DAN MAKNA MEREK (STUDI EMPIRIS PADA J.CO DONUTS \& COFFEE)
}

\author{
Ali Maddinsyah ${ }^{\star}$ dan Nuzul Inas Nabila ${ }^{\star *}$ \\ email : alimaddinsyah@unpam.ac.id
}

\begin{abstract}
ABSTRAK
ANALISIS PEMBENTUKAN EKUITAS MEREK BERDASARKAN CITRA MEREK, WORD OF MOUTH DAN MAKNA MEREK (STUDI EMPIRIS PADA J.CO DONUTS \& COFFEE). Penelitian ini bertujuan untuk mengetahui apakah citra merek, word of mouth dan makna merek merupakan variabel pembentuk ekuitas merek. Sampel penelitian ini adalah 200 pelanggan J.CO di Jakarta Tangerang Selatan dan Depok. Structural Equation Modeling (SEM) dengan software Lisrel 8.80 digunakan untuk menganalisis data. Hasil analisis menunjukkan bahwa citra merek berpengaruh secara langsung dan signifikan terhadap brand meaning, begitu juga dengan word of mouth berpengaruh secara langsung dan signifikan terhadap brand meaning serta citra merek dan word of mouth secara bersama-sama berpengaruh signifikan terhadap brand meaning dan brand meaning mempunyai pengaruh langsung terhadap brand equity sedangkan citra merek tidak terbukti mempunyai pengaruh langsung terhadap brand equity, dan word of mouth tidak terbukti mempunyai pengaruh langsung terhadap brand equity. Hasil temuan yang penting lainnya adalah citra merek, word of mouth, dan brand meaning secara bersama-sama berpengaruh signifikan terhadap brand equity
\end{abstract}

Kata Kunci: Brand Equity, Citra Merek, Brand Meaning, Word of Mouth

\begin{abstract}
ANALYSIS OF BRAND EQUITY BASED ON BRAND IMAGE, WORD OF MOUTH AND BRAND MEANING (EMPIRICAL STUDY ON J.CO DONUTS \& COFFEE). This study aims to find out whether brand image, word of mouth and brand meaning are brand equity forming variables. The sample of this study were $200 \mathrm{~J}$.CO customers in Jakarta, Tangerang Selatan and Depok. Structural Equation Modeling (SEM) with Lisrel 8.80 software is used to analyze data. The results of the analysis show that brand image has a direct and significant effect on brand meaning, as well as word of mouth has a direct and significant effect on brand meaning and brand image and word of mouth together has a significant effect on brand meaning and brand meaning has an influence direct to brand equity while brand image is not proven to have a direct influence on brand equity, and word of mouth is not proven to have a direct influence on brand equity. Other important findings are brand image, word of mouth, and brand meaning together have a significant effect on brand equity
\end{abstract}

Keywords: Brand Equity, Brand Image, Brand Meaning, Word of Mouth

*) Dosen Program Studi Magister Manajemen - Unpam 


\section{PENDAHULUAN}

\section{A. Latar Belakang}

"Membangun merek yang kuat dengan ekuitas yang baik memberikan beberapa manfaat untuk sebuah perusahaan, seperti loyalitas pelanggan, margin yang lebih besar, tanggapan konsumen yang lebih mendukung terhadap kenaikan atau penurunan harga, perdagangan yang baik, meningkatkan efektifitas komunikasi pemasaran, lisensi, dan kesempatan untuk memperluas merek" (Keller, 2001). "Membangun merek yang kuat, sesuai dengan model CBBE (customer based brand equity) pelanggan yang berbasis ekuitas merek mempunyai beberapa tahapan, dimana setiap tahapan tergantung pada keberhasilan langkah sebelumnya" (Keller, 2001).

Tahapan pertama untuk mengidentifisikan merek dengan pelanggan dan asosiasi merek dalam pikiran pelanggan dengan kelas produk tertentu atau kebutuhan pelanggan. Tahapan kedua untuk menetapkan makna merek dibenak pelanggan. Tahapan ketiga untuk memperoleh tanggapan pelanggan yang tepat untuk identitas merek dan makna merek. Tahapan terakhir adalah untuk mengkonversi tanggapan tentang merek dan untuk menciptakan intens, hubungan loyalitas aktif antara pelanggan dan merek (Keller, 2001). "Merek yang kuat akan memudahkan konsumen untuk lebih memvisualisasikan dan memahami produk-produk intangible" (Berry, 2000). Merek yang kuat akan mengurangi perasaan terhadap resiko keselamataan, social, moneter yang mana sulit di evaluasi sebelum membeli.

Anteseden untuk menciptakan kekuatan merek jasa menurut (Berry, 2000) "komponennya antara lain: company's presented brand, brand awareness, external brand communications, brand meaning, customer experience, dan brand equity".

"Komponen presented brand perusahaan merupakan bagian dari citra merek untuk mengontrol melalui semua jaringan personal dan impersonal. Iklan, nama dari merek itu sendiri, website, karyawan, fasilitas, dan semua tipe informasi harus dikordinasikan dan dikontrol" (Zeithaml, Bitner, dan Gremler, 2009). "Nama perusahaan, dan logo merupakan presentasi visual yang dipasang dengan tema iklan, asosiasi-asosiasi simbolik yang merupakan elemen inti yang dihadirkan oleh merek. Citra merek mempunyai pesan merek perusahaan yang dikonsep dan disebarkan. Citra merek mempunyai pengaruh penting untuk memberikan makna terhadap merek dan membangun merek di dalam pikiran pelanggan" (Keller, 2001).

"Komponen untuk menciptakan merek jasa yang kuat, dari external brand communications yang memberikan informasi tentang perusahaan dan jasa yang tidak dapat dikendalikan oleh perusahaan" (Berry, 2000). Komunikasi word of mouth dan publisitas hal yang paling umum untuk external brand communications. Kesadaran akan suatu merek dapat diperoleh tidak hanya dari suatu perusahaan tetapi dapat diperoleh dengan komunikasi dari sumber-sumber independent. "Komunikasi word of mouth adalah bentuk umum pada service untuk sesuatu yang tidak berwujud, aktifitas yang mendapatkan apresiasi tinggi mengenai word of mouth dari pelanggan sebelumnya pilihannya mengenai dokter, pengacara, automobile, mekanik, dan professor" (Berry dan Parasuraman dalam Berry, 2000). "Asosiasi merek ini dapat 
terbentuk langsung dari pengalaman pelanggan sendiri dan kontak dengan merek melalui iklan atau sumber informasi lain word of mouth". (Keller, 2001)

Komponen selanjutnya makna merek yang mempunyai dominan persepsi pelanggan terhadap suatu merek, makna merek menangkap kesan pelanggan dari merek serta assosiasinya terhadap merek. Makna merek, merupakan sesuatu yang ada dipikiran konsumen secara langsung. Makna merek untuk menciptakan ekuitas yang kuat disini merek harus mempunyai asosiasi yang strong, favorable, dan unique.

Komponen dari makna merek mempunyai dampak langsung terhadap ekuitas merek yang mana menurut (Keller, 1993) "ekuitas merek adalah efek diferensial dari kesadaran merek dan makna merek terhadap respon pelanggan mengenai pemasaran merek". "Ekuitas merek dapat positif dan negatif. Positif ekuitas merek menjadi keuntungan bagi pemasaran terhadap merek. Positif ekuitas merek di pemasaran menjadi keuntungan perusahaan untuk memperkuat kesadaran merek dan makna merek. Negatif ekuitas merek menjadi kerugian terkait merek tertentu" (Berry, 2000). Ekuitas merek menerima banyak perhatian dari akademisi dan praktisi pemasaran karena peran penting sebagai key intangible firm asset (Aaker 1991; Keller, 1998) dalam (Seo dan Jang, 2013).

Merek yang kuat untuk di industri makanan, dari Indonesia seperti J.CO donuts dan coffee walaupun baru di industri makanan tetapi J.CO sudah go global ke Malaysia, Singapura, Filipina, dan China, hal ini membuat J.CO dikenal tidak hanya di Indonesia tetapi di negara- negara Asia. J.CO merupakan donat yang mempunyai beragam pilihan rasa, dan mempunyai banyak gerai yang tersebar di Indonesia, tidak hanya itu, J.CO mempunyai tempat yang nyaman untuk makan donat, berdiskusi dan berkumpul dengan teman-teman. J.CO mempunyai strategi untuk menjadi berbeda dari donat lainnya. Seperti pada tabel di bawah ini merupakan top brand kategori donat di Indonesia.

Tabel 1 : Top Brand Kategori Toko Donat

\begin{tabular}{l|l|l|l|l|l|}
\hline \multicolumn{2}{|c|}{ 2016 Fase II } & \multicolumn{3}{c|}{ 2017 Fase II } \\
\hline \multicolumn{1}{|c|}{ Merek } & TBI & TOP & \multicolumn{1}{c|}{ Merek } & TBI & TOP \\
\hline Dunkin Donuts & $51,7 \%$ & TOP & Dunkin Donuts & $46,7 \%$ & TOP \\
\hline J.CO Donuts \& Coffee & $40,6 \%$ & TOP & Starbuck & $44 \%$ & TOP \\
\hline Starbuck & $39,5 \%$ & TOP & J.CO Donuts \& Coffee & $42,1 \%$ & TOP \\
\hline
\end{tabular}

Berdasarkan tabel diatas dapat dijelaskan J.CO Donuts \& Coffee menjadi merek terbaik kedua di Indonesia berdasarkan survey dari Top Brand Award, pada tahun 2016 sebesar 40,6\% dan pada tahun 2017 mengalami peningkatan menjadi 42,1\%. Hal ini dapat membuktikan bahwa J.CO Donust \& Coffee memiliki merek yang cukup baik di mata masyarakat.

J.CO memberikan warna yang baru untuk industry makanan di Indonesia dengan leveraging secondary associations, dimana membangun pelanggan untuk brand equity dengan kesamaan merek yang dapat dikaitkan dengan "country of origin" yaitu, negara yang mana perusahaan membuat produk atau menyediakan layanan sedemikian rupa agar konsumen menyimpulkan keyakinan dan evaluasi (Erickson, 
Johansson, dan chao 1984; Hong dan Wyer 1989, 1990 dalam Kevin Lane Keller 1993). Dimana contohnya nama Perancis untuk anggur, nama Jerman untuk mobil, dan nama elektronik untuk Jepang. J.co melakukan leveraging secondary associations nama J.CO donuts \& Coffee dibuat untuk go global seolah terdengar nama asing untuk membuat keyakinan.

Berdasarkan uraian diatas penulis tertarik untuk melakukan penelitian tentang "Analisis pembentukan ekuitas merek berdasarkan citra merek, word of mouth dan makna merek (studi empiris pada J.CO Donuts \& Coffee)"

\section{B. Perumusan Masalah}

Berdasarkan uraian yang telah penulis kemukakan pada latar belakang masalah dan identifikasi masalah di atas, maka dapat disusun rumusan masalah sebagai berikut:

1. Apakah citra merek berpengaruh terhadap makna merek pada J.CO Donuts \& Coffee?

2. Apakah word of mouth berpengaruh terhadap makna merek pada J.CO Donuts \& Coffee?

3. Apakah citra merek, dan word of mouth secara bersama-sama berpengaruh terhadap makna merek pada J.CO Donuts \& Coffe?

4. Apakah citra merek berpengaruh terhadap ekuitas merek pada J.CO Donuts \& Coffe?

5. Apakah word of mouth berpengaruh terhadap ekuitas merek pada J.CO Donuts \& Coffe?

6. Apakah makna merek berpengaruh terhadap ekuitas merek pada J.CO Donuts \& Coffe?

7. Apakah citra merek, word of mouth dan makna merek secara bersama-sama berpengaruh terhadap ekuitas merek pada J.CO Donuts \& Coffe?

\section{Tujuan Penelitian}

Berdasarkan rumusan masalah di atas penelitian ini bertujuan untuk mengetahui dan membuktikan:

1. Pengaruh citra merek terhadap makna merek pada J.CO Donuts \& Coffe.

2. Pengaruh word of mouth terhadap makna merek pada J.CO Donuts \& Coffe.

3. Pengaruh citra merek, dan word of mouth secara bersama-sama terhadap makna merek pada J.CO Donuts \& Coffe.

4. Pengaruh citra merek terhadap ekuitas merek pada J.CO Donuts \& Coffe.

5. Pengaruh word of mouth terhadap ekuitas merek pada J.CO Donuts \& Coffe.

6. Pengaruh makna merek terhadap ekuitas merek pada J.CO Donuts \& Coffe.

7. Pengaruh citra merek, word of mouth dan makna merek secara bersama-sama terhadap ekuitas merek pada J.CO Donuts \& Coffe. 


\section{LANDASAN TEORI}

\section{A. Citra Merek}

Citra konsumen yang positif terhadap suatu merek lebih memungkinkan konsumen untuk melakukan pembelian. Merek yang baik menjadi dasar untuk citra perusahaan yang positif. Menurut Kotler (2005:629) "citra atau image adalah seperangkat keyakinan, ide dan kesan yang dimiliki oleh seseorang terhadap suatu objek". Image juga didefinisikan sebagai penglihatan secara keseluruhan atau sebuah objek dan serangkaian gambaran mental dan perasaan yang ditimbulkan.

"Citra merek dapat dianggap sebagai jenis asosiasi yang muncul di benak konsumen ketika mengingat sebuah merek tertentu, asosiasi tersebut bisa muncul secara sederhana dalam bentuk pemikiran atau citra tertentu yang dikaitkan kepada suatu merek, asosiasi tersebut juga akan berpengaruh pada sikap konsumen, misalnya suka atau tidak suka" (Shimp,2003:13).

\section{B. Pengaruh citra merek terhadap ekuitas merek}

Citra merek biasanya dianggap sebagai efek gabungan dari asosiasi merek (Biel, 1992) dalam, Faircloth, Capella, dan Alford (2001) atau lebih khusus sebagai persepsi konsumen dari tangible dan intangible asosiasi merek (Engel, Blackwell, dan Miniard, 1993 ) dalam, Faircloth, Capella, Dan Alford (2001).

Peneliti pemasaran telah menyarankan bahwa citra merek merupakan elemen penting dari ekuitas merek (Keller, 1993). Asosiasi merek, yang diperoleh melalui kegiatan bauran pemasaran perusahaan atau penggunaan produk, berkontribusi dan akhirnya menentukan citra merek kepada konsumen (Keller, 1993). Asosiasi yang unik, kuat, dan menguntungkan menciptakan citra merek yang positif dimana ketika diproses oleh konsumen akan ada peningkatan ekuitas merek (Keller, 1993). Selain itu, citra merek yang unik, kuat dan menguntungkan memungkinkan merek dan makna menjadi pembeda dan posisi di benak konsumen, memberikan kontribusi bagi potensi untuk meningkatkan ekuitas merek (Pitta dan Katsanis, 1995) dalam, Faircloth, Capella, dan Alford (2001).

\section{Word of Mouth (WOM)}

Penggunaan praktis dari word of mouth (WOM) dalam konsep pemasaran word of mouth (WOM) merupakanpromosi perusahaan atau produk dan layanan melalui sebuah inisiatif yang disusun dan dirancang untuk membuat orang berbicara positif tentang perusahaan (Kirby dan Marsden, 2006) dalam Pedro Longart (2010). Implikasi dari word of mouth (WOM) digunakan untuk efek yang baik oleh pemasar, seperti yang disimpulkan dari konsep "connected marketing" (Kirby dan Marsden, 2006) dalam Pedro Longart (2010).

Pada pemilihan restoran, niat ke arah makan ditempat tertentu meningkat ketika rekomendasi positif yang diperoleh, dan mempengaruhi keyakinan. Keyakinan ini penting dalam proses pengambilan keputusan. Campbell Smith (1967) dalam Pedro Longart (2010) memperkenalkan (the meal experience model), yang menjelaskan unsur-unsur restoran yang ditawarkan. Cousin et al (2002) dalam Pedro Longart (2010) diklasifikasikan unsur-unsur dalam urutan kepentingan antara lain: (1). makanan dan 
minuman, (2). layanan, (3). kebersihan dan kesehatan (4). nilai terhadap uang (value for money), (5). suasana dan atmosfer.

Beberapa penelitian tentang WOM telah dilakukan sebelumnya dan menghasilkan temuan yang saling melengkapi. Menurut Bone (1992), "WOM adalah pertukaran komentar, pemikiran, atau ide-ide antara dua konsumen atau lebih, dimana tidak satu pun dari mereka adalah sumber pemasar". Definisi itu diperkuat oleh Solomon (2004), "yang menyebutkan bahwa WOM adalah informasi tentang produk yang disalurkan (transmitted) oleh individu ke individu lain".

"WOM dapat terjadi karena adanya kebutuhan, baik oleh pengirim (sender) atau penerima (receiver), akan informasi" (Mowen \& Minor, 1998). Penerima WOM membutuhkan informasi karena mungkin tidak percaya dengan kampanye iklan yang diterimanya, atau mencari informasi tambahan untuk mengurangi resiko membeli produk atau jasa. Bagi pengirim WOM, memberikan informasi dan mempengaruhi konsumen lain dalam pengambilan keputusannya dapat memberikan rasa berkuasa (power) dan gengsi (prestige). Pemberian informasi ini juga membantu pengirim WOM meningkatkan keterlibatan dalam kelompoknya dan mendorong interaksi sosial dan keserasian kelompok secara umum.

Pada konteks proses penyampaian informasi antar konsumen, menurut Bansal et al (2000), "penelitian tentang WOM harus menghadirkan dua hal penting yaitu kekuatan hubungan interpersonal dan hubungan non interpersonal". Dari kedua hubungan itu, di hasilkan tiga keterkaitan yaitu, keterkaitan antara hubungan non interpersonal dengan pengaruh WOM pada keputusan membeli jasa, keterkaitan hubungan interpersonal pada keputusan membeli jasa dan keterkaitan hubungan non interpersonal dengan hubungan interpersonal.

"WOM memiliki bias negatif, dimana informasi negatif dinilai lebih tinggi daripada informasi positif oleh konsumen" (Mowen \& Minor 1998). WOM ini sangat berkaitan dengan pengalaman penggunaan satu merek produk atau jasa. Dalam pengalaman penggunaan produk atau jasa itu akan timbul rasa puas jika produk atau jasa yang digunakan mampu memenuhi harapan konsumen, dan sebaliknya apabila produk atau jasa yang digunakan tidak sesuai harapan sebelumnya. "Dengan pemahaman ini, komunikasi WOM akan berbahaya bagi perusahaan yang mempunyai citra negatif, sebaliknya akan sangat menguntungkan jika dalam komunikasi WOM itu mengenai citra yang baik dan kualitas yang baik" (Ozcan, 2004).

\section{Makna Merek (Brand Meaning).}

Menciptakan makna pada merek, penting untuk menciptakan citra merek dan membangun merek yang ditandai dalam pikiran pelanggan (Keller, 2001). Organisasi membedakan produk mereka melalui branding, dan kurangnya branding yang efektif dapat menyebabkan produk gagal di pasar (Aaker, 2007) dalam (Hollenbeck, Peters, dan Zinkhan 2008). Merek yang kuat dan sukses adalah merek yang sukses bergerak di luar atribut untuk identitas merek didasarkan pada kepribadian merek dan hubungan dengan pelanggan (Aaker, 1994) dalam (Hollenbeck, Peters, dan Zinkhan 2008). Disini makna dari merek merupakan persepsi dominan pelanggan dari suatu merek. Makna 
dari merek juga merupakan kesan yang ditanggap dan juga asosiasi dari suatu merek (Berry, 2000).

Asosiasi merek mendefinisikan makna merek diperoleh terutama melalui pengalaman (baik sendiri atau word of mouth) dengan merek, atau melalui iklan atau sumber informasi. Keller (2013) "mempunyai 3 dimensi antara lain: strength (seberapa kuat merek diidentifikasi dengan asosiasi merek), favorability (seberapa penting atau berharga asosiasi merek untuk pelanggan), dan keunikan (bagaimana khas merek diidentifikasi dengan asosiasi merek)". Asosiasi merek yang kuat, menguntungkan, dan unik dengan konsumen sangat penting untuk membangun positif pelanggan berbasis ekuitas merek. Asosiasi merek ini dapat terbentuk langsung dari pengalaman pelanggan sendiri dan kontak dengan merek melalui iklan atau sumber informasi lain dari word of mouth.

\section{E. Ekuitas merek (Brand Equity)}

"Ekuitas merek adalah nilai tambah pada produk dan jasa" (Kotler dan Keller, 2012). Ini terlihat pada cara konsumen berpikir, merasa, dan bertindak sehubungan dengan merek, serta dalam harga, pangsa pasar, dan profitabilitas merek. Pemasar dan peneliti menggunakan berbagai perspektif untuk mempelajari ekuitas merek. Pendekatan berbasis pelanggan melihatnya dari perspektif konsumen baik individu atau organisasi dan mengakui bahwa kekuatan merek terletak pada apa yang pelanggan lihat, baca, dengar, belajar, berpikir, dan merasa tentang merek dari waktu ke waktu. Aaker (1991) dalam (Kalliala, 2012) "telah mempelajari ekuitas merek menjadi salah satu aset yang paling penting bagi banyak perusahaan dan mendefinisikan ekuitas merek sebagai satu set aset dan kewajiban terkait dengan merek, nama dan simbol, yang menambah atau mengurangi dari nilai yang diberikan oleh produk atau jasa kepada perusahaan atau kepada pelanggan perusahaan" (Aaker, 1991, p.15).

Menurut Aaker (1992) dalam (Kalliala, 2012) lebih lanjut mengakui perbedaan aset dan kewajiban, tergantung pada konteks, tetapi kelompok aset dan kewajiban yang paling penting di bawah lima dimensi yaitu loyalitas merek, kesadaran nama, persepsi kualitas, asosiasi merek dan merek eksklusif lainnya aset, merek dagang, hubungan saluran, dan sebagainya. Berry (2000) menyajikan a service branding model dimana berry menggunakan definisi Keller (1993) dari ekuitas merek (brand) menggunakan arti sebagai citra merek, dan menunjukkan hubungan dari berbagai komponen yang dirancang khusus untuk menciptakan layanan ekuitas merek. Dalam model merek Berry (2000) layanan, ekuitas merek terdiri dari merek yang dihadirkan, pengalaman pelanggan, komunikasi merek eksternal, kesadaran merek, dan makna merek.

Euitas merek dibentuk oleh kesadaran merek (brand awareness) dan makna merek (brand meaning), dengan yang terakhir memiliki pengaruh kuat, dan mengarah pada dampak yang berbeda dua elemen ini terhadap respon pelanggan untuk pemasaran merek (Berry, 2000). "Ekuitas merek positif adalah tingkat keuntungan pemasaran merek yang lebih dari pesaing sedangkan ekuitas merek negatif adalah tingkat kerugian di pasar terkait dengan merek tertentu. (Berry, 2000, p.130). 


\section{F. MODEL PENELITIAN}

Penelitian ini ingin melihat "analisis pembentukan ekuitas merek berdasarkan citra merek, word of mouth dan makna merek (studi empiris pada J.CO Donuts \& Coffee)". Model berdasarkan kerangka penelitian ini memodifikasi dari jurnal (Berry, 2000) A service branding model. Pada industri kesehatan yang karakteristik jasanya banyak interaksi manusia di Berry dan Seltman (2007) "pengaruh utamanya terletak di pengalaman pelanggan, sedangkan peneliti disini ingin melihat pada industri makanan yang intinya pada penawaran makanan, dan lebih tangible dan model berubah karena di industri makanan banyak lebih ke komersial dibandingkan dengan di industri kesehatan, alasan lainnya karena berbeda industri maka konstruk kesadaran merek dan pengalaman pelanggan tidak ikut disertakan, mengingat J.CO sudah terkenal". Disini peneliti memakai konstruk citra merek, word of mouth, makna merek dan ekuitas merek.

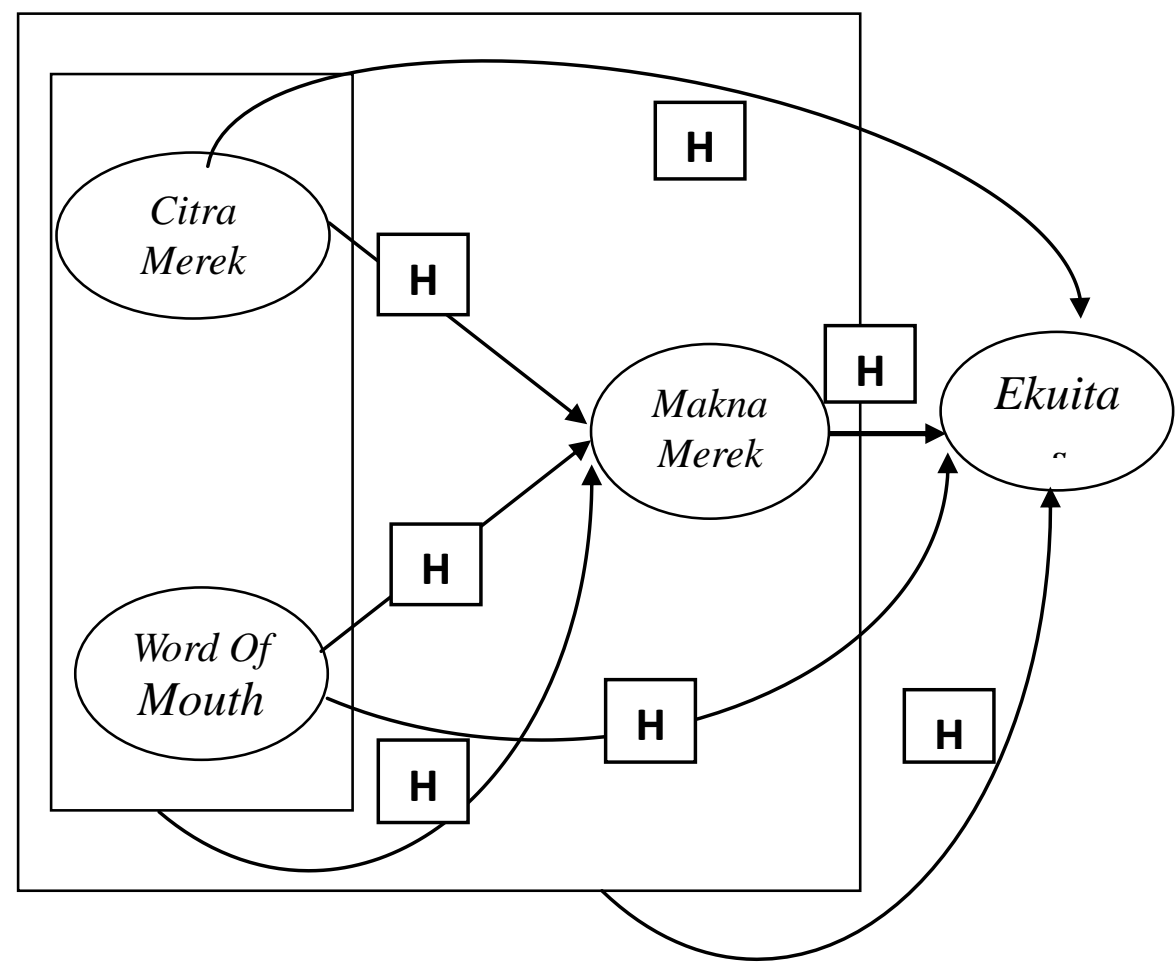

Gambar 1 : Model Penelitian di modifikasi dari Berry (2000)

\section{METODE PENELITIAN}

\section{A. Populasi dan Sampel}

Metode yang digunakan untuk penelitian ini adalah metode kuantitatif yang merupakan pendekatan yang menyangkut pendugaan parameter, pengujian hipotesis, pembentukan selang kepercayaan, dan hubungan antara dua sifat (peubah) atau lebih bagi parameter-parameter yang mempunyai sebaran (distribusi normal) tertentu yang diketahui. Selanjutnya dianalisis menggunakan metode analisis faktor, dan SEM. Unit analisis pada penelitian ini adalah pelanggan J.CO di Jakarta, Depok, dan Tangerang Selatan. 
Populasi dalam penelitian ini adalah J.CO di Jakarta Tangerang Selatan dan Depok yang jumlahnya tidak diketahui. Adapun jumlah sampel yang digunakan dalam penelitian ini sebanyak 200 pelanggan J.CO di Jakarta Tangerang Selatan dan Depok. Pengambilan sampel dilakukan dengan menggunakan Non probability sampling yakni setiap responden memiliki kriteria populasi tidak memiliki kesempatan yang sama untuk menjadi sampel. Lebih tepatnya lagi metode pengambilan sampel ini bersifat convenience sampling, yaitu anggota populasi yang dipilih berdasarkan judgement peneliti. Peneliti memilih responden berdasarkan pengetahuan dan pandangan peneliti yang menilai bahwa seorang yang menjadi anggota populasi tersebut layak untuk menjadi sampel dalam penelitian ini.

\section{B. Operasionalisasi Variabel}

Pada penelitian ini terdapat empat variabel yang diteliti, antara lain citra merek, word of mouth, makna merek, dan ekuitas merek dimana untuk menguji hipotesis penelitian ini, maka setiap variabel diukur dengan menggunakan instrument variabel tersebut.

\section{HASIL DAN PEMBAHASAN}

\section{A. Uji Validitas}

Tujuan dilakukan Pre-test untuk menguji validitas dan reliabilitas alat ukur yang telah ditetapkan pada bab 4. Pre-test dilakukan dengan menyebarkan kuisioner pada 30 responden. Hasil pre-test pada tabel 2 dibawah ini :

Tabel 2. : Uji Validitas Pre-Test $(n=30)$

\begin{tabular}{|c|c|c|c|c|c|c|}
\hline \multicolumn{2}{|r|}{ Variabel } & \multirow{2}{*}{ KMO } & \multirow{2}{*}{ MSA } & \multirow{2}{*}{$\begin{array}{l}\text { Commu } \\
\text { nalities }\end{array}$} & \multirow{2}{*}{$\begin{array}{c}\text { Component } \\
\text { Matrix }\end{array}$} & \multirow{2}{*}{$\begin{array}{l}\text { Kriteria } \\
\text { Validitas }\end{array}$} \\
\hline Latent & Indikator & & & & & \\
\hline \multirow{4}{*}{$\begin{array}{c}\text { Citra } \\
\text { Merek } \\
(\mathrm{CM})\end{array}$} & 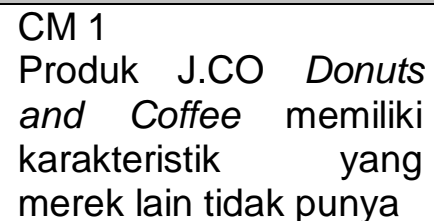 & \multirow[t]{4}{*}{0,668} & 0,820 & 0,634 & 0,796 & Valid \\
\hline & $\begin{array}{l}\text { CM } 2 \\
\text { Merek J.CO Donuts } \\
\text { and Coffee merupakan } \\
\text { merek yang bagus }\end{array}$ & & 0,677 & 0,755 & 0,869 & Valid \\
\hline & $\begin{array}{ll}\text { CM3 } & \\
\text { Merek J.CO donuts } \\
\text { And coffee } & \\
\text { memiliki r kepribadian } \\
\text { yang membedakan } \\
\text { dirinya dari merek } \\
\text { pesaing. } & \\
\end{array}$ & & 0,606 & 0,572 & 0,757 & Valid \\
\hline & $\begin{array}{l}\text { CM } 4 \\
\text { Merek J.CO Donuts } \\
\text { and Coffee tidak akan } \\
\text { mengecewakan } \\
\text { pelanggannya. }\end{array}$ & & 0,678 & 0,672 & 0,820 & Valid \\
\hline
\end{tabular}


JURNAL ILMIAH ILMU MANAJEMEN

\begin{tabular}{|c|c|c|c|c|c|c|}
\hline \multicolumn{2}{|r|}{ Variabel } & \multirow{2}{*}{ KMO } & \multirow{2}{*}{ MSA } & \multirow{2}{*}{$\begin{array}{l}\text { Commu } \\
\text { nalities }\end{array}$} & \multirow{2}{*}{$\begin{array}{c}\text { Component } \\
\text { Matrix }\end{array}$} & \multirow{2}{*}{$\begin{array}{l}\text { Kriteria } \\
\text { Validitas }\end{array}$} \\
\hline Latent & Indikator & & & & & \\
\hline & $\begin{array}{l}\text { CM } 5 \\
\text { J.CO Donuts and } \\
\text { Coffee merupakan } \\
\text { merek terbaik dari } \\
\text { Donuts dan coffee. } \\
\text { (penelitian Alhaddad, } \\
\text { Abdullah Awad 2015) }\end{array}$ & & 0,678 & 0,486 & 0,697 & Valid \\
\hline $\begin{array}{l}\text { WOM } \\
\text { (Word } \\
\text { of } \\
\text { mouth) }\end{array}$ & $\begin{array}{lr}\text { WOM 1 } & \\
\text { Selalu } & \text { memberi } \\
\text { komentar } & \text { positif } \\
\text { terhadap J.CO } & \text { donuts } \\
\text { and coffee } & \end{array}$ & & 0,722 & 0,747 & 0,865 & Valid \\
\hline \multirow[t]{7}{*}{$\begin{array}{l}\text { WOM } \\
\text { (Word } \\
\text { of } \\
\text { mouth) }\end{array}$} & $\begin{array}{l}\text { WOM } 2 \\
\text { Merasa bangga karena } \\
\text { membeli J.co donuts } \\
\text { and coffee }\end{array}$ & \multirow[t]{7}{*}{0,822} & 0,911 & 0,430 & 0,656 & Valid \\
\hline & $\begin{array}{l}\text { WOM } 3 \\
\text { Tahu mengenai detail } \\
\text { dan varian rasa J.co } \\
\text { donuts and coffee }\end{array}$ & & 0,918 & 0,823 & 0,907 & Valid \\
\hline & $\begin{array}{l}\text { WOM } 4 \\
\text { Pernah } \\
\text { merekomendasikan } \\
\text { J.co Donuts and Coffee } \\
\text { kepada teman-teman } \\
\text { saya }\end{array}$ & & 0,821 & 0,629 & 0,793 & Valid \\
\hline & $\begin{array}{l}\text { WOM } 5 \\
\text { Jika keluarga dan } \\
\text { teman-teman saya } \\
\text { sedang berniat untuk } \\
\text { membeli donat, saya } \\
\text { akan } \\
\text { merekomendasikan } \\
\text { J.co Donuts and Coffee } \\
\text { kepada mereka }\end{array}$ & & 0,841 & 0,825 & 0,908 & Valid \\
\hline & $\begin{array}{l}\text { WOM } 6 \\
\text { Saya memberitahu } \\
\text { orang lain tentang } \\
\text { keuntungan J.co donuts } \\
\text { and coffee }\end{array}$ & & 0,737 & 0,645 & 0,803 & Valid \\
\hline & $\begin{array}{l}\text { WOM } 7 \\
\text { Saya memberitahu } \\
\text { orang lain bahwa J.CO } \\
\text { Donuts and Coffee } \\
\text { lebih baik dari yang lain }\end{array}$ & & 0,808 & 0,808 & 0,899 & Valid \\
\hline & $\begin{array}{l}\text { WOM } 8 \\
\text { Saya katakan kepada }\end{array}$ & & 0,899 & 0,545 & 0,738 & Valid \\
\hline
\end{tabular}


JURNAL ILMIAH ILMU MANAJEMEN

\begin{tabular}{|c|c|c|c|c|c|c|}
\hline \multicolumn{2}{|r|}{ Variabel } & \multirow{3}{*}{ KMO } & \multirow{3}{*}{ MSA } & \multirow{3}{*}{$\begin{array}{l}\text { Commu } \\
\text { nalities }\end{array}$} & \multirow{3}{*}{$\begin{array}{c}\text { Component } \\
\text { Matrix }\end{array}$} & \multirow{3}{*}{$\begin{array}{l}\text { Kriteria } \\
\text { Validitas }\end{array}$} \\
\hline Latent & Indikator & & & & & \\
\hline & $\begin{array}{l}\text { mereka bahwa J.CO } \\
\text { Donuts and Coffee ini } \\
\text { memperlakukan saya } \\
\text { lebih baik daripada } \\
\text { pesaing Donuts and } \\
\text { Coffee lainnya. }\end{array}$ & & & & & \\
\hline \multirow{7}{*}{$\begin{array}{l}\text { BM } \\
\text { Brand } \\
\text { meaning }\end{array}$} & $\begin{array}{l}\text { BM } 1 \\
\text { Pengetahuan mengenai } \\
\text { promosi Nike J.co } \\
\text { donuts and coffee } \\
\text { mempunyai citra yang } \\
\text { kuat di mata pelanggan }\end{array}$ & \multirow{7}{*}{0,568} & 0,578 & 0,725 & 0,823 & Valid \\
\hline & $\begin{array}{l}\text { BM } 2 \\
\text { J.co donuts and coffee } \\
\text { mempunyai citra yang } \\
\text { unik di mata pelanggan }\end{array}$ & & 0,629 & 0,446 & 0,612 & Valid \\
\hline & 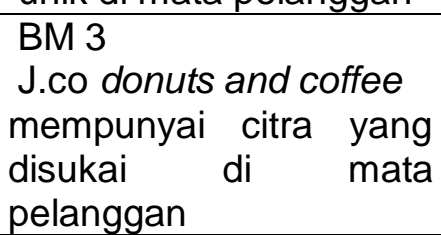 & & 0,577 & 0,772 & 0,769 & Valid \\
\hline & $\begin{array}{l}\text { BM 4 } \\
\text { J.co } \quad \text { memberikan } \\
\text { fasilitas } \quad \text { informasi } \\
\text { seperti kalender, blog } \\
\text { internal dan call center }\end{array}$ & & 0,364 & 0,820 & 0,248 & Valid \\
\hline & $\begin{array}{l}\text { BM } 5 \\
\text { J.co memberikan } \\
\text { umpan balik } \\
\text { pelanggan yang cepat } \\
\text { atau respon yang cepat. }\end{array}$ & & 0,511 & 0,667 & 0,727 & Valid \\
\hline & $\begin{array}{l}\text { BM } 6 \text { memposisikan } \\
\text { J.co dengan } \\
\text { citra merek deng } \\
\text { cara yang konsisten } \\
\text { dengan persepsi dan } \\
\text { interpretasi konsumen } \\
\text { terhadap maknanya } \\
\end{array}$ & & 0,591 & 0,663 & 0,814 & Valid \\
\hline & \begin{tabular}{|l|} 
BM 7 \\
Saluran penjualan \\
memberi informasi \\
penting kepada \\
perusahaan \\
donuts and coffee
\end{tabular} & & 0,643 & 0,519 & 0,671 & Valid \\
\hline$B E$ & $\begin{array}{l}\text { BE } 1 \\
\text { Produk J.co Donuts and } \\
\text { Coffe adalah produk } \\
\text { yang Terkemuka }\end{array}$ & & 0,679 & 0,609 & 0,780 & Valid \\
\hline
\end{tabular}




\begin{tabular}{|c|c|c|c|c|c|c|}
\hline \multicolumn{2}{|r|}{ Variabel } & \multirow{2}{*}{ KMO } & \multirow{2}{*}{ MSA } & \multirow{2}{*}{$\begin{array}{l}\text { Commu } \\
\text { nalities }\end{array}$} & \multirow{2}{*}{$\begin{array}{c}\text { Component } \\
\text { Matrix }\end{array}$} & \multirow{2}{*}{$\begin{array}{l}\text { Kriteria } \\
\text { Validitas }\end{array}$} \\
\hline Latent & Indikator & & & & & \\
\hline $\begin{array}{l}\text { (Brand } \\
\text { Equity) }\end{array}$ & \begin{tabular}{|l} 
BE 2 \\
Produk J.co Donuts and \\
Coffee adalah produk \\
yang berkualitas tinggi
\end{tabular} & 0,781 & 0,841 & 0,796 & 0,892 & Valid \\
\hline \multirow{5}{*}{$\begin{array}{l}\text { (Brand } \\
\text { Equity) }\end{array}$} & \begin{tabular}{|lll} 
BE 3 & & \\
Produk J.co & Donuts \\
and Coffee & adalah \\
produk yang & inovasi \\
dengan & adanya \\
beragam rasa donut
\end{tabular} & \multirow[t]{5}{*}{0,781} & 0,801 & 0,813 & 0,902 & Valid \\
\hline & $\begin{array}{lll}\text { BE } 4 & & \\
\text { Produk J.co } & \text { Donuts } \\
\text { and Coffee adalah } \\
\text { produk pemimpin pasar }\end{array}$ & & 0,804 & 0,751 & 0,867 & Valid \\
\hline & $\begin{array}{l}\text { BE } 5 \\
\text { Produk J.co Donuts } \\
\text { and Coffee mempunyai } \\
\text { bentuk donut yang } \\
\text { enak dipandang }\end{array}$ & & 0,809 & 0,389 & 0,624 & Valid \\
\hline & $\begin{array}{l}\text { BE } 6 \\
\text { Produk J.co Donuts } \\
\text { and Coffee berasal dari } \\
\text { Indonesia }\end{array}$ & & 0,804 & 0,344 & 0,587 & Valid \\
\hline & $\begin{array}{l}\text { BE } 7 \\
\text { Lebih memilih Produk } \\
\text { J.co Donuts and Coffee } \\
\text { daripada merek lain }\end{array}$ & & 0,752 & 0,725 & 0,851 & Valid \\
\hline
\end{tabular}

Berdasarkan Tabel 2 uji validitas di atas, dapat diketahui bahwa semua indikator penelitian (27 indikator) memenuhi kriteria uji validitas sehingga dapat dianalisis lebih lanjut, selanjutnya dilakukan pengujian realibilitas konstruk yang akan digunakan dalam penelitian. Pengujian realibilitas menggunakan cronbach's coefficient alpha. Koefisien alpha cronbach bernilai antara 0 sampai dengan 1 dan batasan nilai alpha cronbach yang umum digunakan adalah lebih besar sama dengan $0,7(\geq 0,7)$. Nilai alpha cronbach kurang dari $0,6(<0,6)$ menindikasikan bahwa realibilitas dari instrumen yang digunakan kurang memenuhi (Hair et al, 2006).

\section{B. Uji Reliabilitas}

Tabel 3. : Hasil Uji Reliabilitas Pre-Test $(n=30)$

\begin{tabular}{|c|c|c|}
\hline Variabel Latent & $\begin{array}{c}\text { Koefisien reliabilitas } \\
\text { Cronbach's Alpha }\end{array}$ & Kriteria Uji \\
\hline CM (Citra Merek) & 0,833 & Reliabel \\
\hline WOM (Word of Mouth) & 0,930 & Reliabel \\
\hline BM (Brand Meaning) & 0,788 & Reliabel \\
\hline BE (Brand Equity) & 0,882 & Reliabel \\
\hline
\end{tabular}

Sumber: Pengolahan Data Oleh SPSS 
Setelah mengukur valid dan reliabel dengan 30 responden konsumen J.CO Donats dan Coffee selanjutnya peneliti menggunakan kuisioner untuk mengumpulkan data dengan jumlah sampel yang lebih besar.

C. Hasil Analisis Data

Model penuh persamaan SEM dengan menggunakan program LISREL 8.80 diperoleh dua model diagram lintasan, yaitu model standardized dan model $t$-values, masing-masing model seperti ditunjukkan pada Gambar 2 berikut :

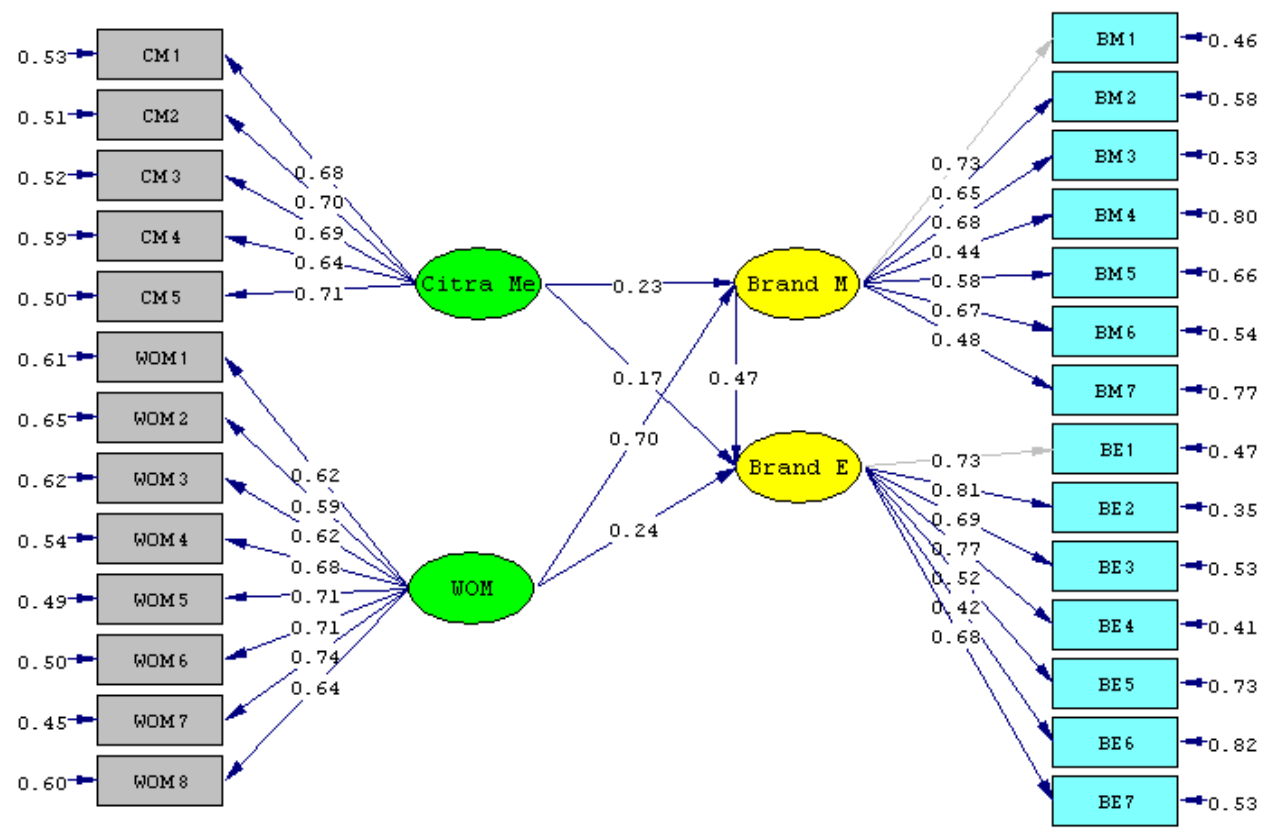

Gambar 2 : SEM (Standardized Model) Second Order

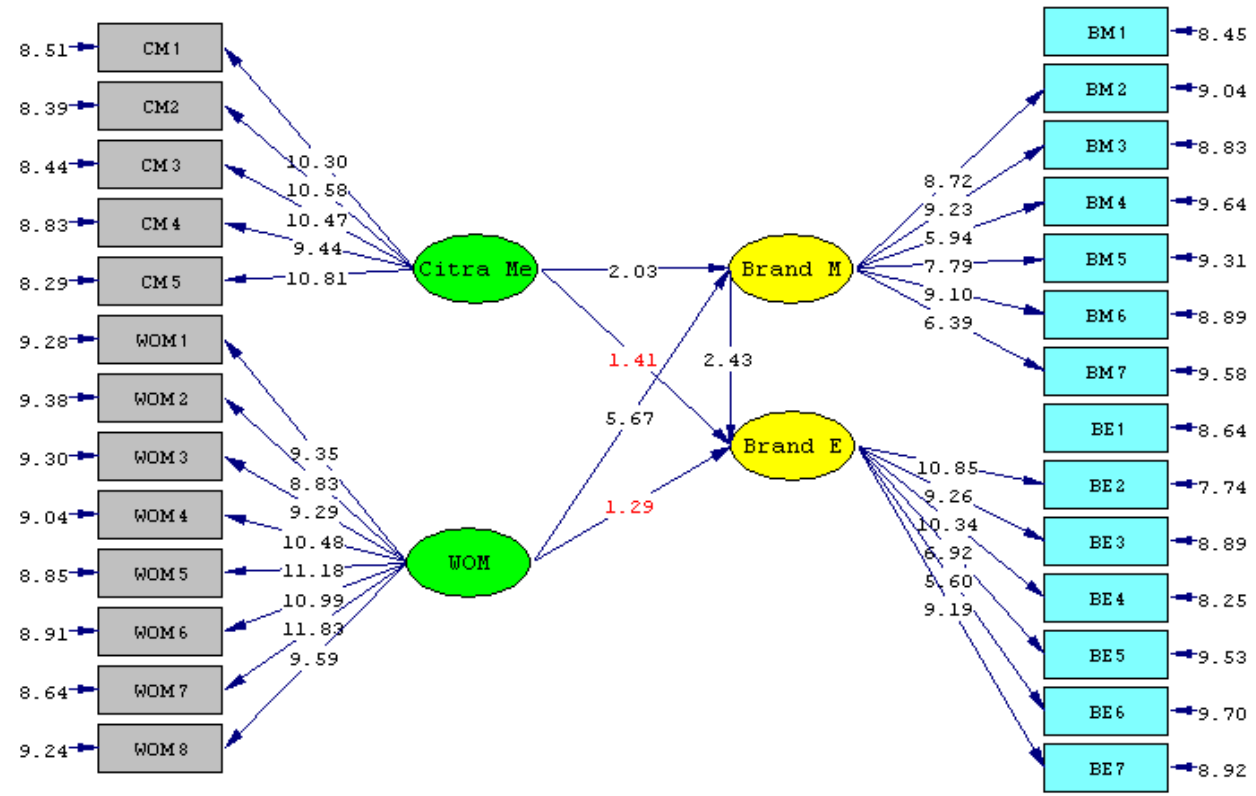

Gambar 3 : SEM ( $t$-value Model) Second Order 
Berdasarkan pada Gambar 2 dan Gambar 3 di atas, selanjutnya akan dikemukakan pengujian parameter $\gamma$ dan $\beta$ (coefficient factor) struktural pada model eksogen maupun endogen. Pengujian ini ditujukan untuk mengetahui pengaruh satu variabel laten terhadap variabel laten lainnya. Pengujian parameter $\gamma$ dan $\beta$ adalah koefisien regresi terstandarisasi (standardized regression weight) untuk variabel eksogen maupun endogen seperti ditunjukkan pada tabel di bawah ini.

Tabel 4 : Uji Statistik Model Persamaan Struktural

\begin{tabular}{|c|c|c|c|c|}
\hline \multicolumn{2}{|r|}{ Structure Models } & \multirow{2}{*}{$\begin{array}{c}\text { Coefficient } \\
\text { Factor } \\
\text { (Standarized } \\
\text { ) }\end{array}$} & \multirow[b]{2}{*}{$\begin{array}{c}t_{\text {hitung }} \\
/ \boldsymbol{F}_{\text {hitung }}\end{array}$} & \multirow[b]{2}{*}{ Hasil uji } \\
\hline $\begin{array}{l}\text { Variabel } \\
\text { Endogen }\end{array}$ & $\begin{array}{c}\text { Variabel Eksogen/ } \\
\text { Endogen }\end{array}$ & & & \\
\hline \multirow{3}{*}{$\begin{array}{l}\text { Brand } \\
\text { meaning }\end{array}$} & Citra merek & 0.23 & 2.03 & Signifikan \\
\hline & Word of mouth & 0.70 & 5.67 & Signifikan \\
\hline & $\begin{array}{l}\text { Citra merek dan Word of } \\
\text { mouth }\end{array}$ & $R^{2}=0.80$ & 10.80 & Signifikan \\
\hline \multirow{4}{*}{$\begin{array}{l}\text { Brand } \\
\text { equity }\end{array}$} & Citra merek & 0.17 & 1.41 & Tidak Signifikan \\
\hline & Word of mouth & 0.24 & 1.29 & Tidak Signifikan \\
\hline & Brand meaning & 0.47 & 2.43 & Signifikan \\
\hline & $\begin{array}{l}\text { Citra merek, Word of mouth, } \\
\text { dan Brand meaning }\end{array}$ & $R^{2}=0.69$ & 10.47 & Signifikan \\
\hline
\end{tabular}

Sumber : Hasil Pengolahan Data, 2018 (LISREL 8.80, $\mathrm{t}_{\text {tabel }}=1,96, \mathrm{~F}_{\text {tabel }}=2.66$ )

Penelitian ini ada 7 (tujuh) hipotesis yang diuji $(\mathrm{H} 1, \mathrm{H} 2, \mathrm{H} 3, \mathrm{H} 4, \mathrm{H} 5, \mathrm{H} 6$, dan $\mathrm{H} 7$ ), dari 7 hipotesis tersebut berdasarkan hasil pengujian tabel di atas, maka diperoleh kesimpulan bahwa $\mathrm{H} 4$ dan $\mathrm{H} 5$ ditolak, sedangkan $\mathrm{H} 1, \mathrm{H} 2, \mathrm{H} 3, \mathrm{H} 6$ dan $\mathrm{H} 7$ diterima. Hasil selengkapnya dari pengujian masing-masing hipotesis dapat dilihat pada tabel di bawah ini.

Dibawah ini hasil uji hipotesis pada

Tabel 5 : Hasil Uji Hipotesis

\begin{tabular}{|c|l|c|}
\hline Hipotesis & \multicolumn{1}{|c|}{ Deskripsi } & Kesimpulan \\
\hline H1 & $\begin{array}{l}\text { Citra merek berpengaruh signifikan terhadap Brand } \\
\text { meaning }\end{array}$ & Diterima \\
\hline H2 & $\begin{array}{l}\text { Word of mouth berpengaruh signifikan terhadap Brand } \\
\text { meaning }\end{array}$ & Diterima \\
\hline H3 & $\begin{array}{l}\text { Citra merek dan Word of mouth secara bersama-sama } \\
\text { berpengaruh signifikan terhadap Brand meaning }\end{array}$ & Diterima \\
\hline H4 & $\begin{array}{l}\text { Citra merek berpengaruh signifikan terhadap Brand } \\
\text { equity }\end{array}$ & Ditolak \\
\hline H5 & $\begin{array}{l}\text { Word of mouth berpengaruh signifikan terhadap Brand } \\
\text { equity }\end{array}$ & Ditolak \\
\hline
\end{tabular}




\begin{tabular}{|c|l|c|}
\hline Hipotesis & \multicolumn{1}{|c|}{ Deskripsi } & Kesimpulan \\
\hline H6 & $\begin{array}{l}\text { Brand meaning berpengaruh signifikan terhadap Brand } \\
\text { equity }\end{array}$ & Diterima \\
\hline H7 & $\begin{array}{l}\text { Citra merek, Word of mouth, dan Brand meaning } \\
\text { secara bersama-sama berpengaruh signifikan } \\
\text { terhadap Brand equity }\end{array}$ & Diterima \\
\hline
\end{tabular}

Sumber : Hasil Pengolahan Data, 2018

\section{Pembahasan}

Hasil pengujian SEM pada struktur 1 menunjukkan citra merek berpengaruh signifikan terhadap brand meaning dengan koefisien regresi sebesar 0.23 dan thitung 2.03, kesimpulannya $\mathrm{HO}$ ditolak dan $\mathrm{Ha}$ diterima. Artinya citra merek secara statistik diprediksikan berpengaruh signifikan terhadap brand meaning J.CO.

Hasil analisis SEM pada struktur 1 menunjukkan word of mouth berpengaruh signifikan terhadap brand meaning dengan koefisien regresi sebesar 0.70 dan t hitung 5.67, kesimpulannya HO ditolak dan Ha diterima. Artinya citra merek secara statistik diprediksikan berpengaruh signifikan terhadap brand meaning J.CO .

Hasil analisis SEM pada struktur 1 menunjukkan citra merek dan word of mouth secara simultan berpengaruh signifikan terhadap brand meaning dengan koefisien determinasi sebesar 0.80 dan $\mathrm{t}$ hitung 10.80 , kesimpulannya $\mathrm{HO}$ ditolak dan $\mathrm{Ha}$ diterima. Artinya citra merek dan word of mouth secara statistik diprediksikan berpengaruh signifikan dan dapat memberikan kontribusi terhadap peningkatan brand meaning sebesar 0,80.

Hasil analisis SEM pada struktur 2 menunjukkan citra merek tidak berpengaruh signifikan terhadap brand equity dengan koefisien regresi sebesar 0.17 dan t hitung 1.41, kesimpulannya HO diterima dan Ha ditolak. Artinya citra merek secara statistik diprediksikan tidak berpengaruh signifikan terhadap brand equity J.CO .Penafsiran dari temuan di atas adalah, (1) citra merek yang terbangun saat ini berdasarkan perhitungan statistik diprediksikan tidak akan memberikan dampak signifikan terhadap brand equity J.CO. (2) temuan ini mengingatkan J.CO bahwa citra merek tidak dapat digunakan untuk meningkatkan brand equity perusahaan, sehingga diharapkan pihak J.CO untuk tidak menggunakan citra merek dalam meningkatkan brand equity perusahaan.

Hasil analisis SEM pada struktur 2 menunjukkan word of mouth tidak berpengaruh signifikan terhadap brand equity dengan koefisien regresi sebesar 0.24 dan t hitung 1.29, kesimpulannya $\mathrm{HO}$ diterima dan Ha ditolak. Artinya word of mouth secara statistik diprediksikan tidak berpengaruh signifikan terhadap brand equity J.CO. Penafsiran dari temuan di atas adalah, (1) word of mouth yang terbangun saat ini berdasarkan perhitungan statistik diprediksikan tidak akan memberikan dampak signifikan terhadap brand equity J.CO . (2) temuan ini mengingatkan J.CO bahwa word of mouth tidak dapat digunakan untuk meningkatkan brand equity perusahaan, sehingga diharapkan pihak J.CO untuk tidak menggunakan word of mouth dalam meningkatkan brand equity perusahaan. 
Hasil analisis SEM pada struktur 2 menunjukkan brand meaning berpengaruh signifikan terhadap brand equity dengan koefisien regresi sebesar 0.47 dan t hitung 2.43, kesimpulannya $\mathrm{HO}$ ditolak dan $\mathrm{Ha}$ diterima. Artinya brand meaning secara statistik diprediksikan berpengaruh signifikan terhadap brand equity J.CO .

Hasil analisis SEM pada struktur 2 menunjukkan citra merek, word of mouth dan brand meaning secara simultan berpengaruh signifikan terhadap brand equity dengan koefisien determinasi sebesar 0.69 dan $\mathrm{t}$ hitung 10.47, kesimpulannya $\mathrm{HO}$ ditolak dan Ha diterima. Artinya citra merek, word of mouth dan brand meaning secara statistik diprediksikan berpengaruh signifikan dan dapat memberikan kontribusi terhadap peningkatan brand equity sebesar 0,69.

\section{KESIMPULAN DAN SARAN}

\section{A. Kesimpulan}

Kesimpulan yang dapat diberikan adalah sebagai berikut:

1. Citra merek berpengaruh signifikan terhadap Brand meaning pada J.CO Donuts \& Coffee, dengan t hitung sebesar 2,03 dan koefisien regresi sebesar 0,23.

2. Word of mouth berpengaruh signifikan terhadap Brand meaning pada J.CO Donuts \& Coffee, dengan t hitung sebesar 5,67 dan koefisien regresi sebesar 0,70.

3. Citra merek dan Word of mouth secara bersama-sama berpengaruh signifikan terhadap Brand meaning pada J.CO Donuts \& Coffee, dengan $t$ hitung sebesar 10.80 dan koefisien regresi sebesar 0,80 .

4. Citra merek tidak berpengaruh signifikan terhadap Brand equity pada J.CO Donuts \& Coffee, dengan t hitung sebesar 1.41 dan koefisien regresi sebesar 0,17.

5. Word of mouth tidak berpengaruh signifikan terhadap Brand equity pada J.CO Donuts \& Coffee, dengan t hitung sebesar 1.29 dan koefisien regresi sebesar 0,24.

6. Brand meaning berpengaruh signifikan terhadap Brand equity pada J.CO Donuts \& Coffee, dengan t hitung sebesar 2.43 dan koefisien dan koefisien regresi sebesar 0.47 .

7. Citra merek, Word of mouth, dan Brand meaning secara bersama-sama berpengaruh signifikan terhadap Brand equity pada J.CO Donuts \& Coffee, dengan t hitung sebesar 10.47 dan koefisien regresi sebesar 0,69 .

\section{B. Saran}

1. Brand meaning terbukti secara statistik berperan sebagai full mediating, artinya karakteristik brand equity J.CO akan terbangun dengan baik apabila citra merek dan word of mouth dapat berpengaruh terhadap brand meaning. Sehingga disarankan kepada perusahaan J.CO Donuts \& Coffee untuk mempertahankan citra merek dan word of mouth yang sudah berjalan baik saat ini, dan tetap memperhatikan brand meaning pelanggan dengan melakukan survey konsumen berkala, sehingga diketahui upaya evaluasi dan perbaikannya.

2. Kepada peneliti selanjutnya, untuk dapat menambah variabel lain sehingga hasil penelitian menjadi lebih berbeda. Selain itu, peneliti selanjutnya dapat melakukan 
modifikasi model dengan metode penelitian dan analisis yang berbeda sehingga akan memunculkan temuan-temuan baru.

\section{Daftar Pustaka}

Aaker, D.A, 1991. Managing Brand Equity: Capitalizing on the Value of a Brand Name. New York: The Free Press.

Aaker, D. A. (1994), "Building a Brand: The Saturn Story," California Management Review, 36 (2), 114-33.

Aaker, D.A. (2007),"Innovation: Brand it or Lose it," California Management Review, 50 (1), 8-24.

Bansal, Harvir S., dan Voyer, Peter A. (2000). Word of Mouth Processes within a Service Purchase Decision Context : Wilfrid Laurier University, University of New Brunswick.Journal of Service Research, Vol. 3, No. 2, 166-177 SAGE Publications.

Beil, Alexander L.(1992), "How Brand Image Drives Brand Equity," Journal of Advertising Research, 12 (November), RC6-RC12.

Berry, L. L. (2000). Cultivating service brand equity.Journal of the Academy of Marketing Science, 28(1), 128-137

Berry, L.L., Seltman D. Kent. (2007). Building a strong services brand: Lessons from Mayo Clinic. Kelley school of business, Indiana University.

Bone, Paula Fitzgerald. (1992) "Determinants Word of Mouth Communication during Product Consumption". Advance in Consumer Research, Vol. 9, Provo, UT: Association for Consumer Research. Pp. 579-583.

Campbell-Smith, G. (1967), The Marketing of the Meal Experience, University of Surrey Press, London.

Cousins, J., Foskett, D. and Gillespie, C. (2002), Food and Beverage Management, 2nd ed., Prentice-Hall, Harlow.

Engel, James F., Roger D. Blackwell, and Paul W. Miniard (1993), Consumer Behavior, Orlando, FL: The Dryden Press

Erickson, Gary M., Johny K. Johansson, and Paul Chao (1984), "Image Variables in Multi- Attribute Product Evaluations: Country-of-Origin Effects,"Journal of Consumer Re-search, 11 (September), 694-9.

Faircloth, Capella, Alford (2001), The Effect of Brand Attitude and Brand Image on Brand Equity, " Journal of Marketing : Theory and Practice

Hair, JF Andersen RE. Tatham RL. And Black W.C (2006), 'Multivariat data analysis, Prentice Hall International, inc Englewood Cliff, NJ.

Hollenbeck., R. Candice., Peters., Cara and Zinkhan., M. George., (2008). Retail Spectacles and Brand Meaning: Insight from a Brand Museum Case Study. Journal of Retailing 84 (3), 334-353

Hong, Sung-Tai and Robert S. Wyer (1989), "Effects of Country-of-Origin and Product Attribute Information on Product Evaluation: An Information 
Processing Perspec- tive,"Journal of Consumer Research, 16 (September), 175- 87.

Hong, Sung-Tai and Robert S. Wyer (1990), "Determinants of Product Evaluation: Effects of the Time Interval BetweenKnowl- edge of a Product's Country of Origin and Information About Its Specific Attributes,"Journal of Consumer Research, 17 (December), 277-88.

Kalliala, Joakim. (2012). Branding in the Retail Banking Industry in Finland - How to attract and retain young consumers.Department of Management and International Business Aalto University School of Business.

Keller, K. L. (1993). Conceptualization, measuring, and managing customer-based brand equity.Journal of Marketing, 57(1), 1-22

Keller, K.L., 1998. Strategic Brand Management: Building, Measuring, and Managing Brand Equity. Upper Saddle River, Prentince Hall, NJ.

Keller, K.L., 2001.Building customer based brand equity. Marketing Management.

Keller, K.L and Kotler, Philip. (2012). Marketing management.14 ${ }^{\text {th }}$. global edition. pearson prenticel hall

Keller, K.L. (2013). Strategic Brand Management: Building, Measuring, and Managing Brand Equity.Global Edition. Pearson

Kirby, J. and Marsden, P. (Eds) (2006), Connected Marketing - The Viral Buzz and Word of Mouth Revolution, Butterworth-Heinemann, Oxford

Longart, Pedro. (2010), “What drives word of mouth in restaurants ?" International Journal of Contemporary Hospitality Management. Vol 22 No. 12010 pp.121-128.

Mowen, John C., dan Minor, Michael. (1998). Consumer Behavior. Prentice Hall Mowen, John. dan Michael Minor. 2002. Perilaku Konsumen, jilid 2, Edisi kelima. Jakarta: Erlangga

Pitta, Dennis A. and Lea Prevel Katsanis (1995), " Understanding Brand Equity for Successful Brand Extension," Journal of Consumer Marketing, Vol.12, No.4, 51-64.

Shimp,Terence, A. (2003).Periklanan promosi aspek tambahan komunikasi pemasaran terpadu. Alih bahasa :Revyani Syahrial dan Dyah Anikasari. Jakarta : Erlangga

Seo, Soobin, Jang (Shawn), SooCheong. (2013) The roles of brand equity and branding strategy: A study of restaurant food crises. International Journal of Hospitality Management, 192-201

Solomon, Michael R. (2004). Consumer Behavior- Buying, Having, and Being $6^{\text {th }}$ Edition: Pearson Education International

Zeithaml, V.A.; Bitner, M.J.; Gremler. 2009. Services Marketing: Integrating Customer Focus Across the Firm. 5th Ed. McGraw Hill: Singapore. (ZBG) 